\title{
Exposure to Sidestream Tobacco Smoke Induces Airway Hyperresponsiveness and Inflammation in Early Postnatal Mice
}

\author{
Wu ZX*, Hunter DD, Batchelor TP and Dey RD
}

Department of Neurobiology and Anatomy, Robert C. Byrd Health Sciences Center, West Virginia University, USA

\begin{abstract}
There are abundant epidemiological studies linking early environmental tobacco smoke (ETS) exposure with childhood asthma. The present study was designed to determine changes on airway responsiveness and innervation after ETS exposure during early postnatal period. The postnatal day (PD) 2 mice were exposed to either ETS or filtered air (FA) for 10 consecutive days. Lung function, substance P (SP) airway innervation, nerve growth factor (NGF) and cytokines in Bronchoalveolar Lavage (BAL) fluid were measured 1, 3 and 7 days after last ETS exposure. 1 day after the last ETS exposure, airway responsiveness and SP innervation in airway smooth muscle were significantly increased, as well as altered airway inflammation, which include significant elevated levels of IL-1 13 , IL4, IL-6, IL-10, TNF $\alpha$ and INF $\gamma$ in BAL compared with FA exposure. Interestingly, 3 days after ETS exposure, airway hyperresponsiveness and SP innervation in airway smooth muscle remained elevated, parallel with high levels of IL-1 and NGF. These results indicated that the change in SP airway innervation play an important roles in airway hyperresponsiveness induced by ETS exposure during early in life.
\end{abstract}

Keywords: Airway innervation; Asthma; Neurokinin receptor; Substance P

Abbreviations: AHR: Airways Hyperresponsiveness; BALF: Bronchoalveolar Lavage Fluid; $\mathrm{C}_{\mathrm{dyn}}$ : Dynamic Pulmonary Compliance; ELISA: Enzyme-Linked Immunosorbent Assay; ETS: Environmental Tobacco Smoke; FA: Filtered Air; MCh: Methacholine; PD: Postnatal Days; $\mathrm{R}_{\mathrm{L}}$ : Pulmonary Resistance; SS: Side-Stream Tobacco Smoke; SP: Substance P

\section{Introduction}

ETS exposure in infants and children increases respiratory symptoms such as coughs, wheezing [1] and airway obstruction [26]. Epidemiological studies show that children are more susceptible to adverse respiratory effects of passive smoking than adults [7], suggesting that exposure to ETS in early development may be a predisposing factor. Indeed, recent studies in animals showed that exposure to ETS during prenatal and early postnatal life produces the changes to lung function [8], indicating a possible critical period of developmental sensitivity to cigarette smoke exposure during the early postnatal period.

Lung and airways are extensively innervated by sensory nerve system. Stimulation of these sensory endings is known to elicit the release of substance $\mathrm{P}(\mathrm{SP})$, which has potent effects on airway smooth muscle tone, vascular permeability and mucus secretion [9-11]. SP plays an important role in antigen or irritant-induced AHR and asthma [12-16]. Our previous study demonstrates that increased SP levels in the airway is involved in cigarette smoke exposure-enhanced airway constriction $[8,16]$. Nerve growth factor (NGF) is a neurotrophic factor that promotes survival, growth, and differentiation of neurons. Our recent studies have shown that NGF is produced in response to irritant exposures and mediates changes in the phenotype and distribution of SP-containing neurons in the airways $[17,18]$. Furthermore, it were reported that inflammatory cytokines and chemokines, especially IL$1 \beta$, mediated NGF and induced airway hyperresponsiveness [19].

Our recent study showed that early postnatal exposure of mice to side-steam tobacco smoke (SS), a surrogate to environmental tobacco smoke (ETS), leads to increased airway responsiveness and innervation late in life [8]. However, the underlying mechanism initiated in early life that affects airway responses remains. Therefore, the goal of the experiment is to identify the possible important cytokines and NGF associated with airway hyperresponsiveness, also to determine the changes of airway neurosensory network structures after SS exposure during early prenatal periods.

\section{Methods}

ICR mice (Harlan, Indianapolis, IN) were housed with access to food and water ad libitum in an FDA approved facility. All procedures were performed in accordance with the recommendations of the Guide for the Care and Use of Laboratory Animals, published by the National Institutes of Health, and the protocols were approved by the WVU Animal Care and Use Committee \#05-0503. The animals were treated humanely and with regard for alleviation of suffering.

\section{SS exposure}

By classical definition, environmental tobacco smoke (ETS) is a diluted mixture of the smoke given off by the burning end of a tobacco product (side stream smoke, $\sim 85 \%$ ) and the smoke exhaled by smokers (mainstream smoke, $\sim 15 \%$ ). Base on previous ETS exposure studies $[8,20,21]$, we used side-stream tobacco smoke (SS) as a surrogate to ETS to identify critical developmental periods of susceptibility.

The postnatal days (PD) 2 mice were used to investigate the effects of ETS exposure. Based on our recent study [8], we have used a design where mice were exposed to either SS or filtered air (FA) six hours per day for ten consecutive days beginning on PD2. The SS exposure

*Corresponding author: Zhong-Xin Wu, Department of Neurobiology and Anatomy, Robert C. Byrd Health Sciences Center, West Virginia University, Morgantown, WV 26506, P.O. Box 9128, USA, Tel: (304) 293-7222; Fax: (304) 293-8159; E-mail: zwu@hsc.wvu.edu

Received September 16, 2013; Accepted October 28, 2013; Published October 31,2013

Citation: Wu ZX, Hunter DD, Batchelor TP, Dey RD (2013) Exposure to Sidestream Tobacco Smoke Induces Airway Hyperresponsiveness and Inflammation in Early Postnatal Mice. J Allergy Ther 4: 153. doi:10.4172/2155-6121.1000153

Copyright: (c) 2013 Wu ZX, et al. This is an open-access article distributed under the terms of the Creative Commons Attribution License, which permits unrestricted use, distribution, and reproduction in any medium, provided the original author and source are credited. 
protocol and methods used in this study have been described in our recently publication [8]. Briefly, mice were randomly placed in an exposure chamber (BioClean, DuoFlo, model H 5500, Lab Products Inc) that measured $1.92 \times 1.92 \times 0.97 \mathrm{~m}\left(3.58 \mathrm{~m}^{3}\right)$. The mice were housed in separate cages located in the exposure chamber. Side-stream smoke from Marlboro filter cigarettes (Phillip Morris, Richmond, VA) was introduced into the exposure chamber at a rate of four cigarettes every 15 minutes for 6 hours per day for 10 days using a smoking machine (RM 1/G, Heinr Borgwald GmbH, Hamburg, Germany). At the end of the 6-hour exposure period, the exhaust fan on the BioClean unit was turned on to rapidly lowered the level of SS in the exposure chamber. The mice were then transported to the animal facilities overnight. The concentrations of carbon monoxide in the exposure chamber were monitored and kept to an average of about 50 parts per million (ppm), relative humidity was about $50 \%$, temperature was about $23^{\circ} \mathrm{C}$. Total suspended particulate concentration was about $1.1 \mathrm{mg} / \mathrm{m}^{3}$, similar to exposure levels used by others to approximate the cloud of particulates surrounding a person during active smoking [21]. The level of nicotine in blood was also measured in some experiments.

In experiments, mice were randomly divided three groups exposed to either SS or filtered air. First group was tracheostomized for measurement of lung function by total pulmonary resistance and dynamic lung compliance at 1 day, 3 days and 7 days after final SS or FA exposure. Second group was sacrificed and the trachea was removed for immunocytochemistry. Third group was used to Bronchoalveolar Lavage (BAL) fluid by injecting and withdrawing sterile saline via the tracheal cannula. The supernatant of BAL fluid was isolated and stored at $-80^{\circ} \mathrm{C}$ for cytokines and NGF assays and pelleted cells were used to analyze the inflammatory cell.

\section{Measurements of lung function}

Lung function was determined by measuring changes of pulmonary resistance and dynamic compliance after aerosolized methacholine (MCh) (Sigma, St. Louis, MO) challenge using a modification of our previously described [8]. Briefly, mice were anesthetized with pentobarbital $(70 \mathrm{mg} / \mathrm{kg}$, intraperitoneally) after SS exposure. The trachea was cannulated just below the larynx via a tracheotomy and a four-way connector was attached to the tracheotomy tube. Two ports were connected to the inspiratory and expiratory tubes of a respirator (Harvard model 683; South Natick, MA). The mice were ventilated at a constant rate of 200 breaths/min and a tidal volume of approximately $0.2 \mathrm{ml}$. Aerosolized MCh was administered for 30 seconds in increasing concentrations $(0,6.25,12.5,25$, and $50 \mathrm{mg} / \mathrm{ml})$. For $5 \mathrm{~min}$ before and after each MCh challenge, total RL and Cdyn were analyzed by computer on a breath-by-breath basis.

\section{Inflammatory cell analysis in Bronchoalveolar Lavage Fluid (BALF)}

BALF was obtained by injecting and withdrawing $1 \mathrm{ml}$ of sterile saline each time for three times (total $3 \mathrm{ml}$ ) via the tracheal cannula at 1 day, or 3 days or 7 days after last SS or FA exposure. The collected BALF (approximately $2.5 \mathrm{ml}$ ) was centrifuged at 1,500 rpm for $10 \mathrm{~min}$. The supernatant was frozen at $-80^{\circ} \mathrm{C}$ for cytokines assays, and the pelleted cells were resuspended in a total of $500 \mu \mathrm{l}$ cold PBS, pooled, plated on glass slides using a cytospin (Shandon Scientific, Ltd., Cheshire, UK) at $400 \mathrm{rpm}$ (18.06 rgf) for $4 \mathrm{~min}$ and stained with Wright-Giemsa on a Hema-Tek 2000 automated slide stainer (Bayer, Inc., Tarrytown, NY). A minimum of 200 leukocytes were counted using a light microscope (Olympus AX70) with a 40 times magnification objective.

\section{Cytokines and NGF Enzyme-Linked Immunosorbent Assay (ELISA)}

BALF supernatants were subsequently analyzed by ELISA for IL-1, IL-4, IL-6, IL-10, TNFa and INF $\gamma$ (BD Biosciences, San Jose, CA), NGF (Promega, Madison, WI) according to the manufacturer's instructions. All samples were run in duplicate or triplicate, and as a negative control, a PBS sample was run with each assay.

\section{Immunocytochemistry}

The procedures for immunocytochemical quantification of airway nerves have been described previously [8,22,23]. Briefly, tracheal segments were removed 1 day, or 3 days or 7 days after the last smoke exposure, and fixed in picric acid-formaldehyde (PAF) fixative for 3 hours, rinsed 3 times with a $0.1 \mathrm{M}$ phosphate-buffered saline containing $0.3 \%$ Triton-X-100 (PBS-Tx), frozen in isopentane, cooled with liquid nitrogen, and stored at $-80^{\circ} \mathrm{C}$. Cryostat sections (12 $\mu \mathrm{m}$ thickness) were collected on gelatin-coated cover slips and dried briefly at room temperature. Then, cryostat sections were covered with rabbit SP antibody (Peninsula Inc, Belmont, CA) diluted 1:100, incubated in a humid chamber at $4^{\circ} \mathrm{C}$ for 24 hours, rinsed with a $1 \%$ bovine serum albumin (BSA)-phosphate saline buffer containing Triton X-100 solution (PBS-Tx plus BSA) three times allowing 5 min for each rinse. The sections were then covered with fluorescein isothiocyanate-labeled goat anti-rabbit antibody (Invitrogen, Carlsbad, $\mathrm{CA}$ ) diluted $1: 100$, incubated at $37^{\circ} \mathrm{C}$ for $30 \mathrm{~min}$, and rinsed. After all immunocytochemical procedures were conducted, the coverslips were mounted with fluoromount and observed under a fluorescence microscope equipped with fluorescein (excitation wavelengths from 455 to $500 \mathrm{~nm}$ and emission wavelengths $>510 \mathrm{~nm}$ ) and rhodamine (excitation 540-504 nm, emission >580) filters. Controls consisted of testing the SP specificity of the primary antiserum by absorption with $100 \mathrm{ng} / \mathrm{ml}$ of SP. Nonspecific background labeling was determined by omission of primary antiserum.

For measuring nerve fiber density in tracheal smooth muscle, we collected SP nerve fibers in series under the Zeiss LSM 510 confocal microscope. A series of images representing all of the tracheal smooth muscle in a section was collected in digital files and saved to an internal database and measured using Optimas software. We selected regions of smooth muscle using the rhodamine channel to avoid possible bias created by the presence or absence of nerve fibers. The smooth muscle regions were outlined to measure total cross-sectional area of smooth muscle. The microscope was then switched to reveal nerve fibers in the fluorescein channel, and the image was digitally captured. The threshold levels were manually adjusted to subjectively optimize the appearance of fluorescent nerves. The area of nerve fibers was determined by segmentation with the Optimas software. Then nerve fiber area was standardized to the total cross-sectional area of smooth muscle. The final value of nerve fiber density is expressed as \% of dividing the SP-nerve fiber area by the total area of smooth muscle. At least 10 measurements were made for each section, and 15 sections were measured in each animal.

\section{Data analysis}

Unless otherwise stated, results are expressed as mean \pm SE. The $R_{L}$ and $\mathrm{C}_{\mathrm{dyn}}$ elicited by MCh were expressed as a percentage of the baseline. Nerve fiber density was expressed as \% area of SP-immunoreactive nerve fibers in the total area of the smooth muscle. Statistical analyses of lung function was performed using one way ANOVA with multiple comparisons, and inflammatory cell and, SP, cytokines and NGF release 
Citation: Wu ZX, Hunter DD, Batchelor TP, Dey RD (2013) Exposure to Sidestream Tobacco Smoke Induces Airway Hyperresponsiveness and Inflammation in Early Postnatal Mice. J Allergy Ther 4: 153. doi:10.4172/2155-6121.1000153

in bronchoalveolar lavage fluid were performed using t-test. A $P$ value $<0.05$ was considered significant, and $n$ represents the number of animals studied.

\section{Results}

\section{The changes of lung function after SS exposure during early postnatal period}

The average nicotine concentration in serum was about $0 \mathrm{ng} / \mathrm{mL}$ after FA exposure. Nicotine measured in the SS-exposed animals at the end of the SS exposure was approximately $20 \mathrm{ng} / \mathrm{mL}$ [95\% confidence interval (CI), 15.3-24.3; $n=6]$, which was similar to nicotine levels typically found in human smokers $(10-50 \mathrm{ng} / \mathrm{mL})[24,25]$. After daily exposure to SS or FA for 10 days, there is no significant difference between the weights of the SS exposure and FA mice (10.4 $\pm 1.1 \mathrm{~g}$ vs. $11.8 \pm 1.2 \mathrm{~g} ; \mathrm{p}=0.40 ; \mathrm{n}=10$, respectively).

The baselines of $\mathrm{R}_{\mathrm{L}}$ and $\mathrm{C}_{\mathrm{dyn}}$ in the different groups were not significantly different before MCh challenge (Table 1 ). However, the $\mathrm{MCh}$ dose-response curves were significantly elevated for $R_{L}$ and significantly decreased for $\mathrm{C}_{\mathrm{dyn}}$ in SS exposed mice (Figure 1) at 1 day and 3 days after SS exposure. For example, a $50 \mathrm{mg} / \mathrm{mL} \mathrm{MCh}$ dose increased $\mathrm{R}_{\mathrm{L}}$ by $328 \%(95 \% \mathrm{CI}, 266-390 \%)$ at 1 day after FA exposure and by $512 \%$ ( $95 \%$ CI, $448-576 \%$; $=0.019)$ at 1 day after SS exposure, and $50 \mathrm{mg} / \mathrm{mL} \mathrm{MCh}$ increased RL by $317 \%$ (95\% CI, 253-381\%) at 3 days after FA exposure and by $466 \%(95 \% \mathrm{CI}, 398-534 \%, \mathrm{p}=0.035)$ at 3 days after SS exposure. The significant differences in the $\mathrm{C}_{\mathrm{dyn}}$ response to MCh between SS- and FA-exposed mice were found at 1day and 3 day after exposure ( $95 \% \mathrm{CI},-54$ to $-38 \%$ vs. -28 to $-36 \%, \mathrm{p}=0.038$,

\begin{tabular}{|c|c|c|c|c|c|c|}
\hline & \multicolumn{2}{|c|}{ 1 day } & 3 days & & \multicolumn{2}{c|}{$\mathbf{7}$ days } \\
\hline & $\mathbf{R}_{\mathrm{L}}$ & $\mathbf{C}_{\text {dyn }}$ & $\mathbf{R}_{\mathrm{L}}$ & $\mathbf{C}_{\text {dyn }}$ & $\mathbf{R}_{\mathrm{L}}$ & $\mathbf{C}_{\text {dyn }}$ \\
\hline
\end{tabular}
\begin{tabular}{l|l|l|l|l|l|l|l|}
\hline SS & $1.01 \pm 0.18$ & $0.069 \pm 0.013$ & $0.99 \pm 0.08$ & $0.067 \pm 0.014$ & $0.98 \pm 0.13$ & $0.066 \pm 0.008$ \\
\hline
\end{tabular} \begin{tabular}{|l|l|l|l|l|l|l|l|}
\hline FA & $0.98 \pm 0.14$ & $0.065 \pm 0.010$ & $0.97 \pm 0.09$ & $0.066 \pm 0.012$ & $0.96 \pm 0.13$ & $0.065 \pm 0.011$ \\
\hline
\end{tabular} $\mathrm{N}=6$ mice in each group, data are means $\pm \mathrm{SE}$

Table 1: The baselines of $\mathrm{R}_{\mathrm{L}}\left(\mathrm{cm} \mathrm{H}_{2} \mathrm{O} / \mathrm{ml} / \mathrm{s}\right)$ and $\mathrm{C}_{\text {dyn }}\left(\mathrm{ml} / \mathrm{cm} \mathrm{H}_{2} \mathrm{O}\right)$ at different times after 10 days SS or FA exposure during early postnatal period
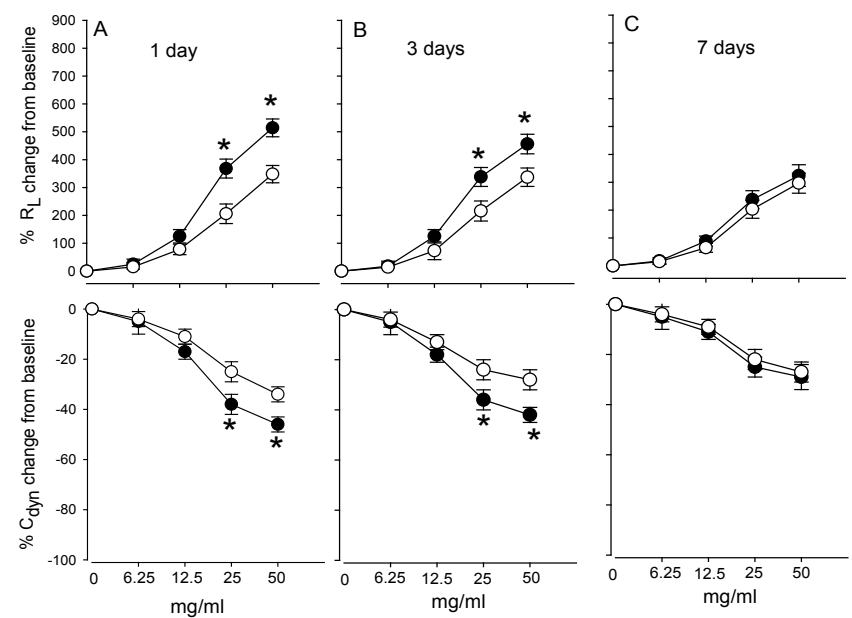

Figure 1: MCh dose responses of $R L$ and Cdyn at 1 day (A), 3 days $(B)$ and 7 days $(C)$ after either 10 days SS or FA exposure during early postnatal periods. Data are means \pm SE of 6 mice in each group

* Significant difference comparing corresponding data between FA and SS animals, $\mathrm{P} \leq 0.05$.
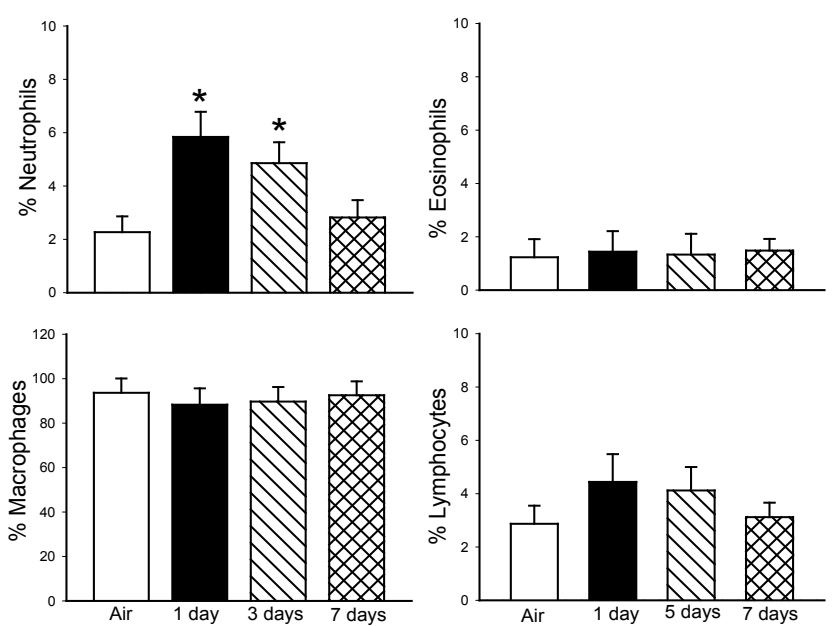

Figure 2: The change of leukocyte counts in Bronchoalveolar Lavage Fluid (BALF) at different time after SS exposure. Data are mean \pm SE of 6 mice in each group.

${ }^{*} \mathrm{P} \leq 0.05$, significant difference between FA- and SS-exposed mice.

1 day after exposure and -48 to $-36 \%$ vs. -34 to $-22 \%, p=0.0473$ day after exposure). However, there is no significant difference in $\mathrm{R}_{\mathrm{L}}$ or $\mathrm{C}_{\mathrm{dyn}}$ responses to $\mathrm{MCh}$ at 7 days after SS exposures. The same $\mathrm{MCh}$ dose produced a $324 \%$ (95\% CI, 256-392\%) increase at 7 days after SS exposure and 298\% (95\% CI, 228-368\%, p=0.61) increase in FA exposure group (Figure 1C).

\section{The changes of airway inflammation and cytokines in BAL} fluid after SS exposure

To determine the differences in the BALF inflammatory cell after CS exposure, the leukocytes in the BAL fluid were collected and observed. The total cells were significantly increased at 1 day $\left(10.44 \pm 0.67 \times 10^{5}\right.$, $\mathrm{p} \leq 0.001)$ and 3 days $\left.8.68 \pm 0.47 \times 10^{5}, \mathrm{p} \leq 0.001\right)$ after SS exposure compared FA exposure $\left(4.36 \pm 0.44 \times 10^{5}\right)$, but the total cells were not significantly different at 7 days $\left(5.22 \pm 0.51 \times 10^{5}, \mathrm{p}=0.24\right)$ after SS exposure. A similar trend was also observed for neutrophils. Statistical analyses found that neutrophils were significantly increased in the BAL fluid at 1 day and 3 days after SS exposure (Figure 2), and returned to control level at 7 days after SS exposure. There is no significant difference in eosinophils and lymphocytes (Figure 2).

Cytokines including IL-1 $\beta$, IL-4, IL-6, IL-10, TNF $\alpha$ and INF $\gamma$ in the BALF were further quantified by ELISA at 1 day, 3 days and 7 days after SS exposure. SS exposure significantly increased the concentrations of IL-1, IL-4, IL-6, IL-10, TNF $\alpha$ and INF $\gamma$ at 1days after SS exposure. The concentrations of IL-1 and TNFa maintained in high levels at 3 days after SS exposure, and returned to control levels at 7 days after SS exposure. However, most of cytokines including IL-4, IL-6, IL-10 and INF $\gamma$ returned to control levels at 3 days after SS exposure (Figure 3).

The changes of SP-immunoreactive nerve fiber density in tracheal smooth muscle after SS exposure during early postnatal period

To determine the effect of SS exposure on SP innervation, the density of SP nerve fibers in the airway smooth muscle were examined at 1 day, 3 days, and 7 days after SS exposure. The density of SP-immunoreactive nerve fibers in tracheal smooth muscle was significantly increased at 1 day and 3 days after SS exposure compared with FA exposed animals (Figure 4). The density of SP-immunoreactive nerve fibers still 

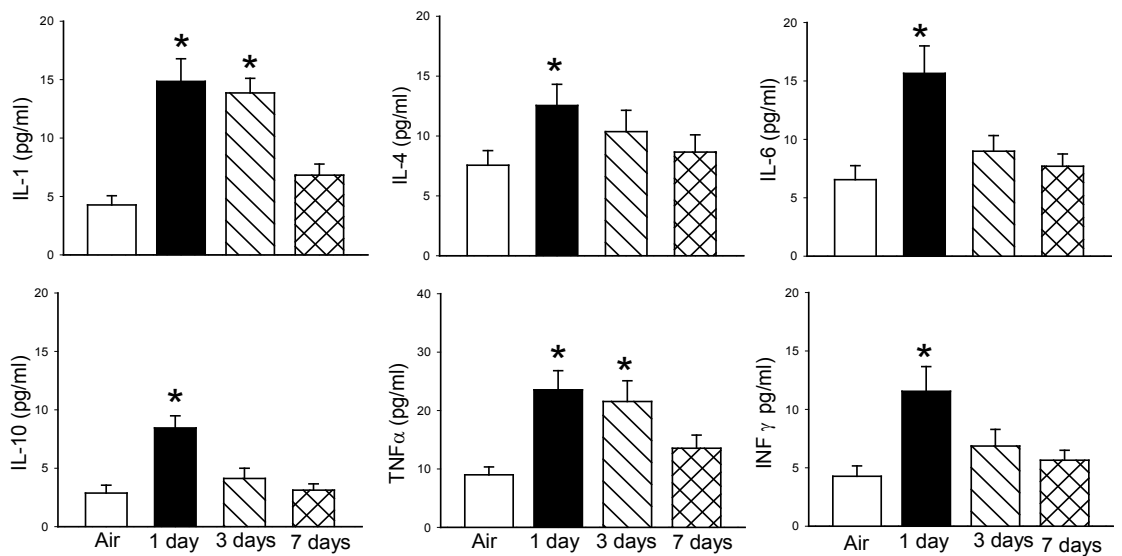

Figure 3: The levels of cytokines release in Bronchoalveolar Lavage Fluid (BALF) at different time after SS exposure. Cytokines were measured by ELISA. Data are mean $\pm \mathrm{SE}$ of 6 mice in each group.

${ }^{*} \mathrm{P} \leq 0.05$, significant difference between FA- and SS-exposed mice.

A
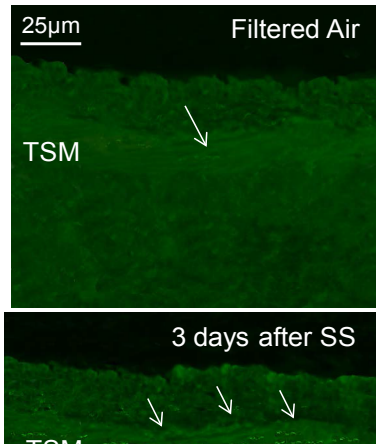

TSM
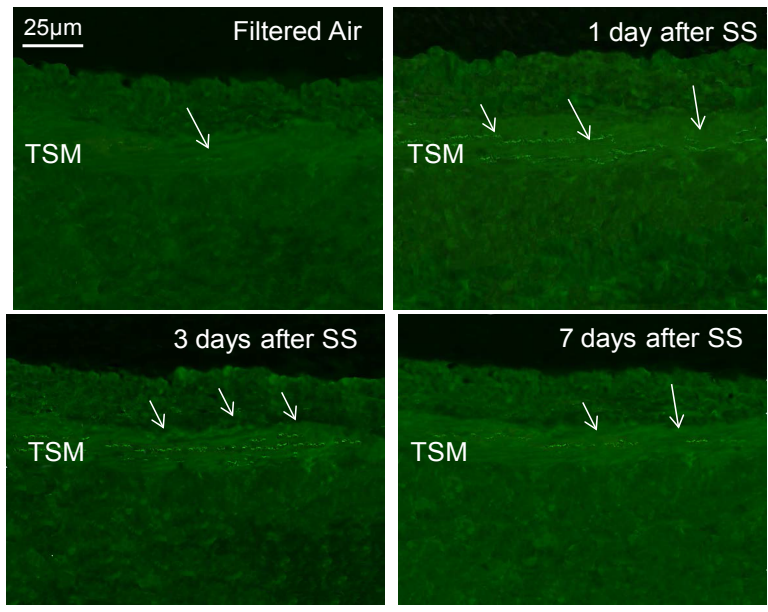

B

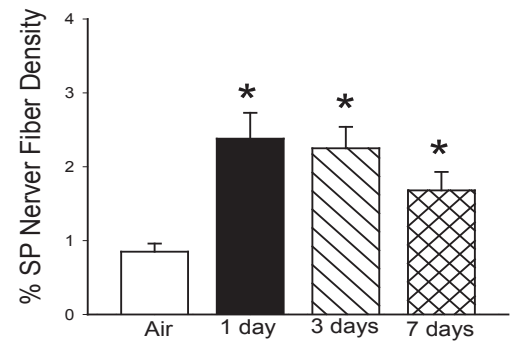

Figure 4: The change of SP nerve fibers in tracheal smooth muscle at different time after SS exposure during early postnatal periods. A: fluorescence photomicrographs of SP nerve fibers in Tracheal Smooth Muscle (TSM) after FA or at 1 days, 3 days and 7 days after SS exposure. B: changes of SP nerve fiber density in tracheal smooth muscle after 10 days FA or at 1 day, 3 days and 7 days after 10 days SS exposure. Arrows: the localization of SP-immunoreactive nerve fibers. Data are mean \pm SE of 6 mice in each group.

${ }^{*} P \leq 0.05$, significant difference between FA- and SS-exposed mice. Magnification: $\times 285$.

maintained high level at 7 day after SS exposure (Figure 4B).

\section{The changes of NGF in BAL fluid after SS exposure during early postnatal period}

Based on our previous studies $[17,18]$ that NGF production was stimulated by irritant exposures and mediated the distribution of SP airway innervations, our next experiment focused on the effects of SS on NGF. The concentrations of NGF in BALF were significantly increased at 1 day and 3 days after SS exposure. However, there was no significant difference at 7 days after SS exposure (Figure 5).

\section{Discussion}

Results obtained from the present study show that exposure to SS during early periods of development significantly elevated bronchomotor responses to MCh at 1 day and 3 days after SS exposure. The exaggerated response is accompanied by the enhanced airway inflammatory reaction, as indicated by the marked increases in the level of neutrophils, IL-1 and TNFa et al. in the BALF (Figure 2 and 3). SP and NGF were also significantly elevated after SS exposure during early developmental period. These data confirmed our recent study that the early postnatal period is a period of susceptibility to inhaled SS in mice [8], indicating that exposure to SS during early postnatal period increased SP may associate with the AHR and exaggerated lung inflammation.

ETS exposure in infants and children increases respiratory symptoms and decreases lung function [2,3,21,26-29]. However, most studies only focus on immune mechanisms that contribute to the development of AHR after ETS exposure. Airway sensitivity and airway responsiveness change with age [30-34]. Innervation of the airways and lung are not fully developed in the early postnatal stage of life. The sensitivity of airway nerves in newborns is higher than adult level [35]. Interestingly, the distribution and density of peptidergic nerves in young children is less than adults [36]. Thus, neurotransmitter is age related and opens the possibility that ETS exposure during periods of rapid lung growth and remodeling may alter the normal developmental process. SP acts as a neuromodulator increasing cholinergic sensitivity of airway smooth muscle [37] and the excitability of airway neurons [38]. Recent studies have showed that SP plays an important role in cigarette smoke-induced asthma [12-16]. Several studies have also found that increased SP synthesis is involved in the pathogenesis of human airway diseases $[13,39]$. These studies show that enhanced SP innervation in human airway sensory nerves may contribute to altered airway function. The current study found that that an initial exposure to SS during early postnatal periods elevated bronchomotor response to MCh, parallel with increased SP level in lung, indicating SP may be 


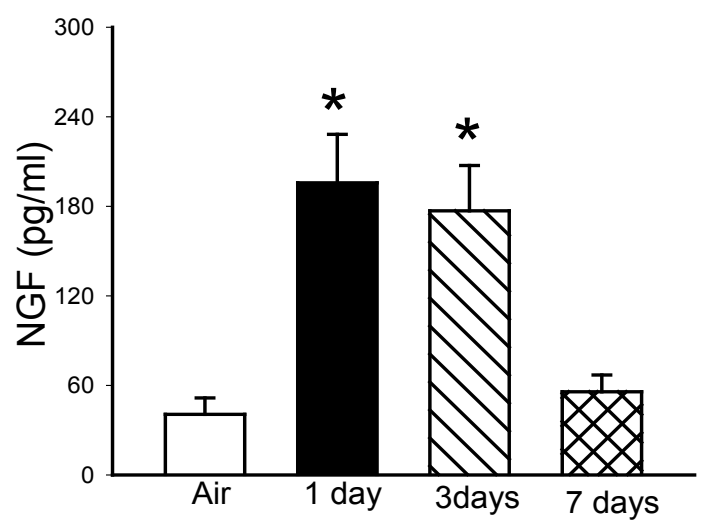

Figure 5: The levels of NGF release in Bronchoalveolar Lavage Fluid (BALF) at different time after SS exposure. NGF was measured by ELISA. Data are mean $\pm \mathrm{SE}$ of 6 mice in each group.

${ }^{*} \mathrm{P} \leq 0.05$, significant difference between FA- and SS-exposed mice.

involved in the pathogenesis of SS-induced AHR. Indeed, the studies in our laboratory found that ETS or ozone exposure during early life enhanced SP nerves in airway in rat and mice, accompanied with change of inflammation and pulmonary lung function $[8,40]$. Cigarette smoke exposure can transiently increase SP in sensory cell bodies projecting to the airways and in axons innervating the airway wall, which modulates cigarette smoke-induced AHR. Although many factors may contribute to early life susceptibility, our studies suggest that detrimental effects of early SS exposures may result in part from altered innervation affecting SP sensory pathways regulating smooth muscle reactivity, bronchial vascular permeability, or mucous secretion.

ETS exposure induces epithelial cell damage and the rapid development of airway inflammation. In the current study, the numbers of neutrophils and cytokines including IL-1 $\beta$, IL-4, IL-6, IL-10, TNFa and INF $\gamma$ in BAL fluid were increased after SS exposure (Figure 2), indicating that SS exposure-produced acute effects involves enhanced airway inflammation. However, increased neutrophils, cytokines and induced airway hyperresponsiveness returned to control levels at 7 days after SS exposure. These data is parallel with our recent publication [8] which showed that FA re-exposure cannot induce airway hyperresponsiveness in mice exposed SS during early postnatal period, indicating that the late effect of SS exposure in life may involve others. SP is associated with inflammation and interacts with other cells in the lung (e.g., mast cells, leukocytes, epithelial cells) to trigger the release of inflammatory mediators [41]. A recent study found that ETS exposure during early life enhanced SP nerves in bronchial epithelium in infant monkeys, accompanied by increased cytokines in the lung [21], indicating that SP are known to have a wide variety of modulatory effects on inflammatory and immune cell. Thus, it is not surprising in the present study that the initial level of SP and inflammation in BAL fluid parallel significantly increased after SS exposure. It is possible that the SP is increased by early responses subsequent to ETS exposure, promoting immune and smooth muscle responses. Indeed, our study [8] showed that SS re-exposure induced airway hyperresponsiveness and altered airway innervation in adult mice which exposed SS during early postnatal period, suggesting the effect of SS on late in life involved the changes of SP airway neurosensory structures.

Nerve growth factor (NGF) is a neurotrophic factor that promotes and maintains growth of the central and peripheral nervous systems, including those that innervate the airways [42]. NGF in the lung increases during gestation and decreases progressively with postnatal age [43].
Disruption of normal synthesis and release of NGF results in changes in airway innervation which leads to disease-related abnormalities in the respiratory system $[17,18,43,44]$. Interestingly, recent study found that high level of NGF expression in lung is associated with the development of airway inflammation and AHR $[45,46]$. We hypothesized that ETS exposure during the early postnatal period alters SP airway innervation, which is possibly mediated by NGF. Current study demonstrated that exposure to ETS during the early postnatal period significantly increased NGF levels in lung, parallel with increased SP and change of lung function after SS exposure; suggesting NGF may regulate SP expression in sensory neurons. There is strong evidence that NGF maintains and even enhances the expression of SP in airway neurons [47]. In mice overexpressing NGF in bronchiolar Clara cells, SP airway innervation is enhanced [48]. Furthermore, our recent study showed that NGF treatment increases SP levels in and around airway neurons and tracheal smooth muscles [22]. These findings, coupled with the current study, support the possibility that NGF serves as a signaling molecule during inflammatory events in the airways by regulating SP production.

In conclusion, the findings of this study show that exposure to SS during early postnatal period significantly induced acute airway hyperresponsiveness and airway inflammation and increased airway innervations. However, increased neutrophils, cytokines and induced airway hyperresponsiveness returned to control levels at 7 days after SS exposure. Combining with our previous publication $[8,16]$, the current study indicates that SS exposure-produced acute effects in lung involve both of airway inflammation and airway innervations, and the late effect of SS exposure during early postnatal mainly involve the change of SP innervation in airway smooth muscle.

\section{Acknowledgments}

This study was supported by American Lung Association BRG 71670136. We are grateful to Dr. Chunlin Dong in the Department of Statistics, West Virginia University, for statistical analysis. All authors declare that they have no competing financial interests.

\section{References}

1. Dodge R (1982) The effects of indoor pollution on Arizona children. Arch Environ Health 37: 151-155.

2. Weitzman M, Gortmaker S, Walker DK, Sobol A (1990) Maternal smoking and childhood asthma. Pediatrics 85: 505-511.

3. Gilliland FD, Berhane K, Li YF, Rappaport EB, Peters JM (2003) Effects of early onset asthma and in utero exposure to maternal smoking on childhood lung function. Am J Respir Crit Care Med 167: 917-924.

4. Håberg SE, Stigum H, Nystad W, Nafstad P (2007) Effects of pre- and postnatal exposure to parental smoking on early childhood respiratory health. Am J Epidemiol 166: 679-686.

5. Raherison C, Pénard-Morand C, Moreau D, Caillaud D, Charpin D, et al. (2007) In utero and childhood exposure to parental tobacco smoke, and allergies in schoolchildren. Respir Med 101: 107-117.

6. Wang C, Salam MT, Islam T, Wenten M, Gauderman WJ, et al. (2008) Effects of in utero and childhood tobacco smoke exposure and beta2-adrenergic receptor genotype on childhood asthma and wheezing. Pediatrics 122: e107-114.

7. Lebowitz MD, Sherrill D, Holberg CJ (1992) Effects of passive smoking on lung growth in children. Pediatr Pulmonol 12: 37-42.

8. Wu ZX, Hunter DD, Kish VL, Benders KM, Batchelor TP, et al. (2009) Prenatal and early, but not late, postnatal exposure of mice to sidestream tobacco smoke increases airway hyperresponsiveness later in life. Environ Health Perspect 117: $1434-1440$.

9. Barnes PJ, Baraniuk JN, Belvisi MG (1991) Neuropeptides in the respiratory tract. Part I. Am Rev Respir Dis 144: 1187-1198. 
Citation: Wu ZX, Hunter DD, Batchelor TP, Dey RD (2013) Exposure to Sidestream Tobacco Smoke Induces Airway Hyperresponsiveness and Inflammation in Early Postnatal Mice. J Allergy Ther 4: 153. doi:10.4172/2155-6121.1000153

10. Lundberg JM, Martling CR, Saria A (1983) Substance $P$ and capsaicin-induced contraction of human bronchi. Acta Physiol Scand 119: 49-53.

11. Lundberg JM, Hökfelt T, Martling CR, Saria A, Cuello C (1984) Substance P-immunoreactive sensory nerves in the lower respiratory tract of various mammals including man. Cell Tissue Res 235: 251-261.

12. Lundberg JM, Martling CR, Saria A, Folkers K, Rosell S (1983) Cigarette smoke-induced airway oedema due to activation of capsaicin-sensitive vagal afferents and substance P release. Neuroscience 10: 1361-1368.

13. Ollerenshaw SL, Jarvis D, Sullivan CE, Woolcock AJ (1991) Substance P immunoreactive nerves in airways from asthmatics and nonasthmatics. Eur Respir J 4: 673-682.

14. Wu ZX, Satterfield BE, Dey RD (2003) Substance P released from intrinsic airway neurons contributes to ozone-enhanced airway hyperresponsiveness in ferret trachea. J Appl Physiol (1985) 95: 742-750.

15. Wu ZX, Morton RF, Lee LY (1997) Role of tachykinins in ozone-induced airway hyperresponsiveness to cigarette smoke in guinea pigs. J Appl Physiol (1985) 83: 958-965.

16. Wu ZX, Lee LY (1999) Airway hyperresponsiveness induced by chronic exposure to cigarette smoke in guinea pigs: role of tachykinins. J Appl Physiol (1985) 87: 1621-1628.

17. Wilfong ER, Dey RD (2004) Nerve growth factor and substance P regulation in nasal sensory neurons after toluene diisocyanate exposure. Am J Respir Cell Mol Biol 30: 793-800

18. Wilfong ER, Dey RD (2005) The release of nerve growth factor from the nasal mucosa following toluene diisocyanate. J Toxicol Environ Health A 68: 1337-1348.

19. Frossard N, Naline E, Olgart Höglund C, Georges O, Advenier C (2005) Nerve growth factor is released by IL-1beta and induces hyperresponsiveness of the human isolated bronchus. Eur Respir J 26: 15-20.

20. Pinkerton KE, Joad JP (2000) The mammalian respiratory system and critical windows of exposure for children's health. Environ Health Perspect 108: 457-462.

21. Yu M, Zheng X, Peake J, Joad JP, Pinkerton KE (2008) Perinatal environmental tobacco smoke exposure alters the immune response and airway innervation in infant primates. J Allergy Clin Immunol 122: 640-647.

22. Wu ZX, Dey RD (2006) Nerve growth factor-enhanced airway responsiveness involves substance $\mathrm{P}$ in ferret intrinsic airway neurons. Am J Physiol Lung Cell Mol Physiol 291: L111-L118.

23. Dey RD, Satterfield B, Altemus JB (1999) Innervation of tracheal epithelium and smooth muscle by neurons in airway ganglia. Anat Rec 254: 166-172.

24. WHO (2003) IPCS: Environmental Health Criteria Series. Carbon Monoxide.

25. Benowitz NL, Jacob P 3rd (1984) Daily intake of nicotine during cigarette smoking. Clin Pharmacol Ther 35: 499-504.

26. Chilmonczyk BA, Salmun LM, Megathlin KN, Neveux LM, Palomaki GE, et al. (1993) Association between exposure to environmental tobacco smoke and exacerbations of asthma in children. N Engl J Med 328: 1665-1669.

27. Gilliland FD, Berhane K, McConnell R, Gauderman WJ, Vora H, et al. (2000) Maternal smoking during pregnancy, environmental tobacco smoke exposure and childhood lung function. Thorax 55: 271-276

28. Frischer T, Kuehr J, Meinert R, Karmaus W, Barth R, et al. (1992) Maternal smoking in early childhood: a risk factor for bronchial responsiveness to exercise in primary-school children. J Pediatr 121: 17-22.

29. Ronchetti R, Bonci E, Cutrera R, De Castro G, Indinnimeo L, et al. (1992) Enhanced allergic sensitisation related to parental smoking. Arch Dis Child 67: 496-500.

30. Aberg G, Adler G (1973) The effect of age on -adrenoceptor activity in tracheal smooth muscle. Br J Pharmacol 47: 181-182.

31. Clerici C, Harf A, Gaultier C, Roudot F (1989) Cholinergic component of histamine-induced bronchoconstriction in newborn guinea pigs. J Appl Physiol (1985) 66: 2145-2149.
32. Duncan PG, Douglas JS (1985) Age-related changes in guinea pig respiratory tissues: considerations for assessment of bronchodilators. Eur J Pharmacol 108: 39-48.

33. Wu ZX, Yang QH, Ruan T, Lee LY (2004) Influence of maturation on constrictive response to stimulation of C-fiber afferents in isolated guinea pig airways. Am J Physiol Lung Cell Mol Physiol 287: L168-L175.

34. Sparrow MP, Mitchell HW (1990) Contraction of smooth muscle of pig airway tissues from before birth to maturity. J Appl Physiol (1985) 68: 468-477.

35. Larsen GL, Loader J, Nguyen DD, Fratelli C, Dakhama A, et al. (2004) Mechanisms determining cholinergic neural responses in airways of young and mature rabbits. Pediatr Pulmonol 38: 97-106.

36. Hislop AA, Wharton J, Allen KM, Polak JM, Haworth SG (1990) Immunohistochemical localization of peptide-containing nerves in human airways: age-related changes. Am J Respir Cell Mol Biol 3: 191-198.

37. Cheung D, van der Veen H, den Hartigh J, Dijkman JH, Sterk PJ (1994) Effects of inhaled substance $P$ on airway responsiveness to methacholine in asthmatic subjects in vivo. J Appl Physiol (1985) 77: 1325-1332.

38. Myers AC, Undem BJ, Weinreich D (1990) Electrophysiological properties of neurons in guinea pig bronchial parasympathetic ganglia. Am J Physiol 259: L403-L409.

39. O'Connell F, Springall DR, Moradoghli-Haftvani A, Krausz T, Price D, et al. (1995) Abnormal intraepithelial airway nerves in persistent unexplained cough? Am J Respir Crit Care Med 152: 2068-2075.

40. Hunter DD, Wu Z, Dey RD (2010) Sensory neural responses to ozone exposure during early postnatal development in rat airways. Am J Respir Cell Mol Biol 43: 750-757.

41. Joos GF, Pauwels RA (2000) Pro-inflammatory effects of substance P: new perspectives for the treatment of airway diseases? Trends Pharmacol Sci 21: 131-133.

42. Levi-Montalcini $R$ (1987) The nerve growth factor: thirty-five years later. Biosci Rep 7: 681-699.

43. Hu C, Wedde-Beer K, Auais A, Rodriguez MM, Piedimonte G (2002) Nerve growth factor and nerve growth factor receptors in respiratory syncytial virusinfected lungs. Am J Physiol Lung Cell Mol Physiol 283: L494-L502.

44. Tortorolo L, Langer A, Polidori G, Vento G, Stampachiacchere B, et al. (2005) Neurotrophin overexpression in lower airways of infants with respiratory syncytial virus infection. Am J Respir Crit Care Med 172: 233-237.

45. Renz H, Kiliç A (2012) Neurotrophins in chronic allergic airway inflammation and remodeling. Chem Immunol Allergy 98: 100-117.

46. Scuri M, Samsell L, Piedimonte G (2010) The role of neurotrophins in inflammation and allergy. Inflamm Allergy Drug Targets 9: 173-180.

47. Shadiack AM, Sun Y, Zigmond RE (2001) Nerve growth factor antiserum induces axotomy-like changes in neuropeptide expression in intact sympathetic and sensory neurons. J Neurosci 21: 363-371.

48. Hoyle GW, Graham RM, Finkelstein JB, Nguyen KP, Gozal D, et al. (1998) Hyperinnervation of the airways in transgenic mice overexpressing nerve growth factor. Am J Respir Cell Mol Biol 18: 149-157. 